\title{
Peanut Seed Cultivars with Contrasting Resistance to Aspergillus parasiticus Colonization Display Differential Temporal Response of Protease Inhibitors
}

\author{
Virginia Müller, Gustavo Bonacci, Carlos Batthyany, María V. Amé, Fernando Carrari, Jorge Gieco, and Ramón Asis
}

First, second, fourth, and seventh authors: Departamento de Bioquímica/CIBICI, Facultad de Ciencias Químicas, Universidad Nacional de Córdoba, Haya de la Torre interseccion Medina Allende, Ciudad Universitaria, CP5000, Córdoba, Argentina; third author: Unidad de Bioquímica y Proteómica Analítica, Institut Pasteur de Montevideo; fifth author: Instituto de Biotecnología, Instituto Nacional de Tecnología Agropecuaria, Hurlingham, Buenos Aires, Argentina; and sixth author: Instituto Nacional de Tecnología Agropecuaria, Estación Experimental Manfredi, Córdoba, Argentina.

Accepted for publication 9 November 2016.

\begin{abstract}
Significant efforts are being made to minimize aflatoxin contamination in peanut seeds and one possible strategy is to understand and exploit the mechanisms of plant defense against fungal infection. In this study we have identified and characterized, at biochemical and molecular levels, plant protease inhibitors (PPIs) produced in peanut seeds of the resistant PI 337394 and the susceptible Forman cultivar during Aspergillus parasiticus colonization. With chromatographic methods and 2D-electrophoresis-mass spectrometry we have isolated and identified four variants of Bowman-Birk trypsin inhibitor (BBTI) and a novel Kunitz-type protease inhibitor (KPI) produced in response to A. parasiticus colonization. KPI was detected only

in the resistant cultivar, while BBTI was produced in the resistant cultivar in a higher concentration than susceptible cultivar and with different isoforms. The kinetic expression of $K P I$ and $B B T I$ genes along with trypsin inhibitory activity was analyzed in both cultivars during infection. In the susceptible cultivar an early PPI activity response was associated with BBTI occurrence. Meanwhile, in the resistant cultivar a later response with a larger increase in PPI activity was associated with BBTI and KPI occurrence. The biological significance of PPI in seed defense against fungal infection was analyzed and linked to inhibitory properties on enzymes released by the fungus during infection, and to the antifungal effect of KPI.
\end{abstract}

Plant protease inhibitors (PPIs) are important elements of the plant defense machinery against insects, nematodes, and phytopathogenic microorganisms. In insects and nematodes, PPIs obstruct the enzyme activity of the digestive tract and suppresses the normal assimilation of food proteins. In phytopathogenic microorganisms, the defense role of PPIs is attributed to the inhibition of the secreted proteases necessary for entering plant cells and supplying the pathogen with nutrients (reviewed by Hörger and van der Hoorn 2013; Mosolov and Valueva 2005; Yarullina et al. 2016). In addition, members of PPI family have shown antimicrobial activity such as cysteine protease inhibitor of sunflower seeds, millet, and snuff against Fusarium and Trichoderma (Joshi et al. 1998; Kouzuma et al. 2000; Park et al. 2000) or different maize protease inhibitors against several pathogens (Carrillo et al. 2011; Chen et al. 1999; Roberts and Selitrennikoff 1990).

Peanut seeds as hypogeous fruits are in direct contact with soil fungal populations, and are frequently colonized by mycotoxigenic fungi such as Aspergillus flavus and A. parasiticus. Success of seed colonization depends on the skill of the fungus to pass through the outer barrier and exploit the nutrients from the seeds. In a previous report, we have proposed that protease production by A. parasiticus is related to infection and aflatoxin contamination in peanuts. This contributes to generating tissue damage affecting seed viability and germination, providing access to fungus invasion through the integument (Asis et al. 2009). The use of enzymes as tools to degrade physical barriers by various pathogenic fungi is directly related to the production of proteolytic enzymes (Chen et al. 2009; Vernekar and Deshpande 1999). Serine and metallo proteases were described as

Corresponding author: R. Asis; E-mail address: rasis@fcq.unc.edu.ar

*The $\boldsymbol{e}$-Xtra logo stands for "electronic extra" and indicates that five supplementary figures and one supplementary table are published online.

(c) 2017 The American Phytopathological Society the main fungal extracellular proteases produced by A. flavus and A. parasiticus during colonization of peanut seed (Asis et al. 2009).

Given the role of fungal proteases during seed colonization, seed protease inhibitors would be important pieces in the defense against aflatoxin-producing Aspergillus. Differential gene expression studies with peanut seeds in response to $A$. parasiticus infection have reported an increase in protease inhibitor gene expression after fungal inoculation (Guo et al. 2008; Luo et al. 2005a, b). However, the role of these proteins in peanut seed defense is still not clearly understood. The aim of this research was to identify PPIs from peanut seed in response to $A$. parasiticus challenge and to explore their role in seed defense and fungal colonization resistance. Here, we report the identification and characterization of two PPIs and their gene expression patterns in peanut seeds from two cultivars with contrasting behavior against $A$. parasiticus infection, by applying proteomic tools and real-time PCR. Additionally, different functions of both PPIs in seed defense were discussed.

\section{MATERIALS AND METHODS}

Plant material. Peanut seeds of the two cultivars were provided by the Instituto Nacional de Tecnología Agropecuaria (INTA, Manfredi Experimental Station, Córdoba, Argentina). The PI 337394 cultivar was previously characterized as resistant and the Florman INTA cultivar as susceptible to Aspergillus spp. infection (Asis et al. 2005).

Seed samples of tested cultivars were obtained from the same growing season (2010 to 2011). The cultivars were grown in a tworow plot of $10 \mathrm{~m}$ long, with a spacing of $0.70 \mathrm{~m}$ between rows and $20 \mathrm{~cm}$ between plants within row, in a completely randomized block design with two replicates. For weed and leaf spot control, Imazetapir $(100 \mathrm{ml} / \mathrm{ha})$ and Cletodin $(175 \mathrm{ml} / \mathrm{ha})$ herbicides and Mancozeb (1 kg/ha) fungicide were applied. Two complementary irrigations $(50 \mathrm{~mm})$ were carried out in February and March to avoid drought stress. Each cultivar was manually harvested at its optimum maturity and threshed. Harvested pods, naturally dried to $5.5 \%$ 
moisture, were hand-sorted to remove and discard visibly damaged pods and stored in bags in a seed chamber at $7^{\circ} \mathrm{C}$ until use. Pods were hand-shelled before performing the experiments.

Aspergillus spp. source. Isolate number 18 of A. parasiticus was used for all the experiments reported here. This isolate was previously determined as highly aflatoxigenic and infective in peanut seeds (Asis et al. 2005). The fungi were grown on potato dextrose agar (PDA) (Merck) at $30^{\circ} \mathrm{C}$ for 7 days. Spore suspensions were obtained by washing the surface of the cultures with Tween $80(0.5 \mathrm{ml} / \mathrm{liter})$ and quantified in a Neubauer chamber.

Infection assay and seed treatment. For all experiments, seeds without tegument of both cultivars (PI 337394 and Florman INTA) were surface-sterilized with sodium hypochlorite. Disinfected seeds were inoculated with $1 \mathrm{ml}$ of spore suspension of $A$. parasiticus $\left(1 \times 10^{4}\right.$ spores $\left./ \mathrm{ml}\right)$ and incubated at $30^{\circ} \mathrm{C}$ in Petri dishes. Control seeds received an equal amount of Tween 80 (mock inoculated). For PPIs purification, seeds were incubated for $48 \mathrm{~h}$.

For gene expression analysis, three independent biological replicates were conducted in parallel and samples were collected at 5, 10, 20, 27, 48, and $72 \mathrm{~h}$ after inoculation (hai).

In each sample collected, seeds were examined by visual inspection to identify the presence or absence of mycelium; the percentage of colonized seed was then calculated.

PPIs extraction and acetone precipitation. Seeds were lyophilized for $16 \mathrm{~h}$ and then ground and defatted with chilled hexane $\left(-20^{\circ} \mathrm{C}\right)$ using an Ultraturrax T18 basic (IKA Works Inc.). Defatted meals were used to extract PPIs with a solution of glacial acetic acid $(0.05 \mathrm{M}) 1: 10, \mathrm{wt} / \mathrm{vol}$, using Ultraturrax T18. The homogenate was centrifuged at $12,000 \times g$ for $10 \mathrm{~min}$ at $4^{\circ} \mathrm{C}$. Subsequently, proteins were precipitated twice by acetone fractionation with addition of cold acetone at $30 \%, \mathrm{vol} / \mathrm{vol}$, and $70 \%, \mathrm{vol} / \mathrm{vol}$, consecutively, overnight at $-20^{\circ} \mathrm{C}$. Samples were then centrifuged at $13,000 \mathrm{rpm}$ for $10 \mathrm{~min}$ at $4^{\circ} \mathrm{C}$ and resuspended in buffer $20 \mathrm{mM}$ Tris- $\mathrm{HCl}(\mathrm{pH}$ 6.4).

PPIs purification. PPIs were isolated by ion exchange chromatography using fast protein liquid chromatography (FPLC) equipment (Amersham Bioscience). The PPIs extract was loaded on a Mono Q HR 5/5 $(1 \mathrm{ml})$ column equilibrated with $30 \mathrm{ml}$ of $20 \mathrm{mM}$ Tris- $\mathrm{HCl}$ (pH 7.5) solution A. The column was washed with $10 \mathrm{ml}$ of solution $\mathrm{A}$ and protein elution was performed with a linear gradient of 0 to $100 \% 0.5 \mathrm{M} \mathrm{NaCl}$ in solution A. The flow rate was $60 \mathrm{ml} / \mathrm{h}$ and the absorbance of eluates was monitored at $280 \mathrm{~nm}$.

The fractions collected in the void volume of the ion exchange chromatography were subjected to a second step of chromatographic separation through a molecular filtration. For that purpose, a Bio-Gel $\mathrm{P}$ (Bio-Rad) was used. The separation was performed with $50 \mathrm{mM}$ Tris- $\mathrm{HCl}(\mathrm{pH} 6.8) / 200 \mathrm{mM} \mathrm{NaCl}$ at a flow rate of $15 \mathrm{ml} / \mathrm{h}$.

In both chromatographic analyses, fractions of $0.5 \mathrm{ml}$ were collected and their trypsin inhibitory was activity evaluated.

Two-dimensional gel electrophoresis. Proteins of selected fractions of anionic and gel permeation chromatography were precipitated with acetone $70 \%$, resuspended in a $20 \mathrm{mM}$ Tris- $\mathrm{HCl}$ buffer ( $\mathrm{pH}$ 8.9) solution, and treated with the kit (2D Clean-up kit, Amersham Biosciences) to remove interfering substances. The first dimension analysis was performed with isoelectric focusing Ettan IPGphor 3 (Amersham Biosciences) using IPG strips (pH 3 to 10, $7 \mathrm{~cm})$. IPG strips were rehydrated with sample solution $(0.125 \mathrm{ml})$ in the rehydration IPG box (Amersham Biosciences) for 10 to $24 \mathrm{~h}$ at room temperature. Strips were then covered with mineral oil (fluid cover, Amersham Biosciences) and run in four steps with $6299 \mathrm{Vh}$ at $20^{\circ} \mathrm{C}$. They were removed and incubated for $15 \mathrm{~min}$ with a $50 \mathrm{mM}$ Tris- $\mathrm{HCl}$ buffer ( $\mathrm{pH} 8.8$ ) solution containing $6 \mathrm{M}$ urea; $30 \%$ (vol/vol) glycerol; $2 \%$ (wt/vol) sodium dodecyl sulfate (SDS); $1 \%$ (vol/vol) DTT; and $0.002 \%$ (wt/vol) bromophenol blue. The solution was then removed and replaced with another one containing the same components, except that DTT was replaced with $4 \%$ (wt/vol) iodoacetamide. The strips were positioned on a SDS-polyacrylamide gel electrophoresis (PAGE) at 16\% and proceeded to run at a constant current of $50 \mathrm{~mA}$. The stacking gel was prepared at $4 \%$ (wt/vol) acrylamide in $0.5 \mathrm{M}$ Tris- $\mathrm{HCl}$ ( $\mathrm{pH} 6.8$ ) solution, while resolving gel was prepared at $16 \%$ (wt/vol) acrylamide in $1.5 \mathrm{M}$ Tris- $\mathrm{HCl}(\mathrm{pH}$ 8.8). Electrophoretic analysis was performed with a constant current of $30 \mathrm{~mA}$ at $4^{\circ} \mathrm{C}$ on a Mini PROTEAN III electrophoresis cell (Bio-Rad Laboratories), using electrophoresis solution: $0.1 \mathrm{M}$ Tris- $\mathrm{HCl}$ (pH 8.3); $0.1 \mathrm{M}$ tricine; and $0.1 \%$ (wt/vol) SDS (sodium lauryl sulfate) (Schägger 2006).

Proteins were detected by staining with Coomassie Brilliant Blue R250 and molecular weight was calculated from a calibration curve with commercial molecular weight marker protein (log molecular weight versus relative mobility) (Bio-Rad).

Identification of 2D gel protein spots by MALDI-TOF/ TOF. Proteins of excised gel plugs were digested with trypsin for $16 \mathrm{~h}$ (Promega, sequencing grade). Peptides were extracted from gel with a solution of $60 \%(\mathrm{vol} / \mathrm{vol})$ acetonitrile with $0.2 \%(\mathrm{vol} / \mathrm{vol})$ trifluoroacetic acid, concentrated by vacuum drying, and desalted using C18 (Omix, Varian). Eluted peptides were injected directly into the mass spectrometer with $3 \mu \mathrm{l}$ of matrix solution ( $\alpha$-cyano- 4 hydroxycinnamic acid in $60 \%$ (vol/vol) acetonitrile with $0.2 \%$ (vol/ vol) trifluoroacetic acid acid). The mass spectrum of the digested samples was performed on a MALDI-TOF/TOF (Biosystems) mode and reflector equipment externally calibrated with a mixture of peptide standards (Biosystems). Proteins were identified with NCBI nr database using search with the values of $\mathrm{m} / \mathrm{z}$ and MASCOT program with the following preselected parameters: mono isotopic mass tolerance of $0.05 \mathrm{Da}$; fragment mass tolerance of $0.25 \mathrm{Da}$; methionine oxidation and tryptic cleavage as fixed modifications.

Trypsin inhibitory assay. The inhibitory activity was determined spectrophotometrically using $0.1 \%$ (wt/vol) of benzoyl$\alpha$-arginine p-nitroaniline (Sigma) as substrate. An aliquot of $47 \mu \mathrm{l}$ of eluted fractions was mixed with $233 \mu \mathrm{l}$ of substrate, $47 \mu \mathrm{l}$ of trypsin $(1,000 \mu / \mathrm{ml}$ in $1 \mathrm{mM} \mathrm{HCl}$, Sigma) and buffer triethanolamine $/ 20 \mathrm{mM} \mathrm{CaCl} 2(\mathrm{pH} \mathrm{7.8})$ up to $1 \mathrm{ml}$ final volume. The absorbance was scanned at $405 \mathrm{~nm}$, every $1 \mathrm{~s}$ (during $5 \mathrm{~m}$ ) at $25^{\circ} \mathrm{C}$ in a Shimadzu UV1601 spectrophotometer. One trypsin inhibitory unit (TIU) will decrease the activity of two trypsin units by $50 \%$, where one trypsin unit will hydrolyze $1 \mu$ mol benzoyl- $\alpha$-arginine p-nitroaniline per minute at $\mathrm{pH} 7.8$ at $25^{\circ} \mathrm{C}$. TIU: $(\Delta \mathrm{Abs} / \mathrm{min}$ of uninhibited control $-\Delta \mathrm{Abs} / \mathrm{min}$ of sample $) / 9.96\left(\mathrm{mM}^{-1} \times \mathrm{cm}^{-1} \mathrm{EC}\right.$ p-nitroaniline $) \times(\mathrm{ml} \mathrm{sample} / \mathrm{ml}$ reaction $\mathrm{mix})$.

PPI activity in reverse zymography. SDS-PAGE at $16 \%$ was performed as described in second-dimension electrophoresis, with the addition of $0.1 \%(\mathrm{wt} / \mathrm{vol})$ casein in the polymerization of acrylamide. The electrophoretic run was performed at $100 \mathrm{~V}$ at $4^{\circ} \mathrm{C}$ on a Mini Protean III electrophoresis cell (Bio-Rad Laboratories), using electrophoresis solution: $0.1 \mathrm{M}$ Tris- $\mathrm{HCl}(\mathrm{pH} 8.3), 0.1 \mathrm{M}$ tricine, and $0.1 \%$ (wt/vol) SDS. The PPI samples were loaded onto the gels in a sample buffer containing $10 \%$ (wt/vol) glycerol, $0.001 \%$ (wt/vol) bromophenol blue, and $20 \mathrm{mM}$ dithiothreitol without heating to avoid loss of activity. After electrophoresis, the gel was incubated for $1 \mathrm{~h}$ in a solution of $2.5 \%$ (wt/vol) Triton X-100 to remove the SDS.

After $1 \mathrm{~h}$, all lines except that containing molecular weight markers were placed in a $0.01 \%$ (wt/vol) trypsin (Trypsin $250 \mathrm{BD}$ Difco) solution in $10 \mathrm{mM}$ Tris- $\mathrm{HCl}$ (pH 7), $200 \mathrm{mM} \mathrm{NaCl}$, and $10 \mathrm{mM}$ $\mathrm{CaCl}_{2}$ and incubated at $37^{\circ} \mathrm{C}$ for $8 \mathrm{~h}$. Following proteolysis, the gels were stained with $125 \mathrm{mg}$ of Coomassie Brilliant Blue R250 in 40\% (vol/vol) methanol and $10 \%$ (vol/vol) acetic acid. Then gel destaining was performed with a solution of $5 \%$ methanol and $10 \%$ acetic acid.

Fungal protease inhibition in zymography study. In the zymography test, the enzymes were separated by electrophoresis and detected by their ability to hydrolyze casein in the migration region according to Asis et al. (2009). A. parasiticus was incubated in casein liquid medium at $30^{\circ} \mathrm{C}$ for 10 days. The culture medium was filtered and the extracellular proteases were precipitated from the filtered culture medium by the addition of $-20^{\circ} \mathrm{C}$ cold acetone ( $80 \%$ of total volume). The precipitate was dissolved in $50 \mathrm{mM}$ phosphate buffer ( $\mathrm{pH} 7)$. The enzyme extracts were diluted (1/4) in sample buffer containing SDS without reducing agents and not 
boiled before loading onto the gels. Electrophoresis was carried out using $10 \%$ acrylamide copolymerized with sodium casein at $1 \mathrm{~g} /$ liter (Sigma-Aldrich) in a vertical electrophoresis system Mini PROTEAN III (Bio-Rad) at a constant voltage of $100 \mathrm{~V}$ in an ice bath. After electrophoresis, the gel was washed with Triton X-100 and incubated for $48 \mathrm{~h}$ at $37^{\circ} \mathrm{C}$ in an enzyme buffer $(50 \mathrm{mM}$ Tris$\mathrm{HCl}(\mathrm{pH} 7.5), 200 \mathrm{mM} \mathrm{NaCl}$, and $1.8 \mathrm{mM} \mathrm{CaCl}_{2}$ ) with the presence of PPI obtained by precipitation with acetone $70 \%$ (see PPIs extraction and acetone precipitation) or absence of inhibitor (control). After incubation, the gels were stained with $5 \mathrm{~g} / \mathrm{liter}$ Coomassie Brilliant Blue $\mathrm{G} 250$ in $30 \%$ (vol/vol) methanol and $10 \%$ (vol/vol) acetic acid. The unstained regions showed protease migration in the gels. Protease activity in the gels was estimated by densitometric analysis using Image J software (Image J 1.43u, Schneider et al. 2012). To inhibit the four classical protease groups (metallo, serine, cysteine, and aspartic protease), $10 \mathrm{mM}$ EDTA (Sigma-Aldrich), $5 \mathrm{mM}$ PMSF (Sigma-Aldrich), $100 \mu \mathrm{M}$ iodoacetamide (Sigma-Aldrich), and $1 \mathrm{mM}$ pepstatin A (Sigma-Aldrich) were used, respectively.

Antifungal assay. For the antifungal assay, an aliquot of eluted fraction $(0.010 \mathrm{ml})$ was incubated with a $90 \mu \mathrm{l}$ of $A$. parasiticus suspension $\left(1 \times 10^{4}\right.$ spores $\left./ \mathrm{ml}\right)$ in Mueller Hinton liquid medium with chloramphenicol $(0.045 \mathrm{ml} / 50 \mathrm{ml})$ at $37^{\circ} \mathrm{C}$ for $24 \mathrm{~h}$. After the incubation period the absorbance at $600 \mathrm{~nm}$ was determined to express the development of fungal mycelium, confirmed by microscopic observation.

Gene expression analyses. qRT-PCR was performed according to Müller et al. (2014). In brief, total RNA was extracted from 10 frozen seeds per replicate with the plant RNeasy kit (Qiagen) and RNA samples were treated with DNase I (Fermentas) to remove contaminating DNA. A quantity $(1 \mu \mathrm{g})$ of this RNA was used to prepare cDNA using Revert Aid M-MuLV reverse transcription (Fermentas). Gene expression was quantified by qRT-PCR analyses using a Bio-Rad iQ cycler with $1 \mu \mathrm{l}$ of a dilution of cDNA (50 ng reverse-transcribed total RNA), SYBR Green PCR Master Mix spiked with fluorescein $10 \mathrm{nM}$ (Applied Biosystems) and $0.3 \mu \mathrm{M}$ primers in a final volume of $15 \mu \mathrm{l}$. Primers were designed by using the Primer Express TM (Applied Biosystems) software based on sequences deposited in GenBank under the following accession numbers: AY330200.1 for BBTI, ES761053 for KTI, and AY378165 for Histone H3. Primer information on each gene is shown in Supplementary Table S1. Gene-specific PCR amplification efficiency was calculated using the following equation: efficiency $\%=$ $\left(10^{\wedge}(-1 /\right.$ slope $\left.)-1\right) \times 100$. Histone $\mathrm{H} 3$ encoding gene $(H 3$, AY378165) was used as a reference gene according to expression stability for normalization of gene expression.

Statistical analyses. Statistical analyses were carried out using the InfoStat Software Package (InfoStat 2002). All values are expressed as means \pm standard deviation. All data were subjected to analysis of variance (ANOVA). When significant differences were found by ANOVA, the Fisher test was used to compare treatments. When not normally distributed, data were subjected to nonparametric statistical analysis on ranks (Kruskal-Wallis) followed by Dunn's posttest. Significance was accepted at $P<0.05$ for all comparisons.

\section{RESULTS}

PPI purification and identification. In order to identify proteins with protease inhibitory activity in peanut seeds during fungal

TABLE 1. Trypsin inhibitor units (TIU) activity of proteins precipitated at different acetone percentages starting from peanut seed extract of infected seeds of PI 337394 and Florman cultivar ${ }^{\mathrm{a}}$

\begin{tabular}{lcc}
\hline & \multicolumn{2}{c}{ Peanut cultivars } \\
\cline { 2 - 3 }$\%(\mathrm{vol} / \mathrm{vol})$ acetone & PI 337394 & Florman \\
\hline 30 & $4.81 \pm 0.03$ & $0.32 \pm 0.21$ \\
70 & $50.66 \pm 2.23^{*}$ & $32.41 \pm 4.21^{*}$ \\
\hline
\end{tabular}

a TIU is expressed per microgram of protein. $*$ indicates significant differences between acetone treatment. infection, we inoculated with $A$. parasiticus spores onto two cultivars with contrasting behavior in relation to this fungus: Florman (susceptible) and PI 337394 (resistant). The external seed infection was measured by visual inspection after $48 \mathrm{~h}$ of incubation at $30^{\circ} \mathrm{C}$ (Supplementary Fig. S1). The percentage of colonized seeds was $90 \pm 7$ and $6 \pm 3 \%$ of total inoculated seeds in the susceptible and resistant cultivar, respectively.

To explore whether the differences in fungal colonization are related to protease inhibitor expression, PPIs were extracted from defatted meals of infected and control seeds (mock inoculated). Subsequently PPIs were isolated by cold acetone fractionation where the main PPI activity was detected at $70 \%$ of acetone fraction (Table 1). PPI activity was higher in fractions derived from infected seeds when compared against those derived from control seeds. These PPIs were then purified by anion exchange chromatography (AEC) (Fig. 1A). In order to detect PPI activity, the fractions eluted were collected and subjected to trypsin inhibitory activity assay (Fig. 1B) and reverse zymography (Fig. 1C). The main PPI activity was detected in the fraction 1,2, and 3 (AEC 1-3), corresponding to unbound proteins, and in the fraction 17,18 , and 19 eluted at 8 to $10 \%$ of solvent B (AEC 17-19) (Fig. 1A and B). The reverse zymography assay of fraction 17, 18, and 19 exhibited PPI activity at molecular weight between 16.9 and $14.4 \mathrm{kDa}$ (Fig. 1C). In both assays, the fraction AEC 17-19 of resistant cultivar showed higher PPI activity compared with the susceptible cultivar (Fig. 1B and C).

Fractions AEC 1-3 were pooled and separated by gel permeation chromatography (GPC) as shown in the chromatogram of Figure 2A. The main trypsin inhibitory activity was detected in the fractions 14,15 , and 16 (GPC 14-16) (Fig. 2B). In these fractions, reverse zymography analysis exhibited PPI activity between 6.5 and $14.4 \mathrm{kDa}$ (Fig. 2C). In both PPI assays (Figs. 2B and 2C), GPC 14-16 fraction of resistant cultivar showed higher PPI activity than the susceptible cultivar.

To identify these proteins, fractions AEC 17-19 and GPC 14-16 corresponding to resistant and susceptible cultivar were separated by 2D-SDS-PAGE (Figs. 3 and 4) and all spots were subsequently analyzed by MALDI-TOF. Peptide sequences were compared against NCBI database nr (nonredundant protein sequences) and NCBI Peanut EST database. A total of 18 proteins were identified from the AEC 17-19 fraction of both cultivars (Fig. 3A and B). These protein profiles changed markedly between cultivars and most of these proteins were exhibited in the resistant cultivar (PI 337394). The identified proteins are listed in Table 2. Only the protein $\mathrm{Cu}-\mathrm{Zn}$-super oxide dismutase could be found in both cultivars, while the remaining proteins were specific to each cultivar. Among the proteins identified in the resistant cultivar, we could find proteins related to: metabolism (16 $\mathrm{kDa}$ malate dehydrogenase, triose phosphate isomerase, trans aldose), stress (glutathione transferase, lactoyl glutathione lyase, glyoxalase, glutaredoxin, $\mathrm{Cu}-\mathrm{Zn}$-super oxide dismutase, and allergen Ara h 8), and protease inhibitory activity (Kunitz-type protease inhibitor) (Fig. 3A and Table 2). In contrast, in the susceptible cultivar different proteins related to metabolism ( $22 \mathrm{kDa}$ malate dehydrogenase) and to stress (mannose binding lectin, galactose-binding lectin and $\mathrm{Cu}-\mathrm{Zn}$-super oxide dismutase) were found, whereas no protease inhibitors were detected (Fig. 3B and Table 2).

Two-dimensional gel electrophoresis of GPC 14-16 fractions from PI 337394 and Florman cultivars are shown in Figure 4A and B, respectively. Thirteen protein spots were identified in these gels (Table 3). Proteins related to: stress (Cu-Zn-super oxide dismutase and pathogenesis-related protein class IV) and protease inhibitor activity (Bowman-Birk type inhibitor (BBTI): AI, BI and BIII isoforms) were found in both cultivars. However, other proteins were specific to PI 337394 cultivar such as those related to stress (BBTI AII isoform, allergen Ara $\mathrm{h}$ 8, and glutaredoxin) and to protein modification (ubiquitin), while a galactose-binding lectin was found only in the Florman cultivar (Table 3). The densitometry analysis of BBTI isoforms found in both cultivars showed higher levels of these inhibitors in the resistant cultivars (PI 337394, spot area of BIII: 6100, BI: 4600, and AI: 4000; Florman, spot area of BIII: 4700, BI: 3800, and AI: 3200). 
Sequence and phylogenetic analyses. Considering the results from 2D-SDS-PAGE, the PPI activity observed in fractions AEC 17-19 is mainly based on the presence of Kunitz protease inhibitor (KPI) encoded by peanut EST ES761053 (Table 2). The product of this gene is a protein with a conserved Kunitz inhibitor domain, which has not been previously described (Supplementary Fig. S2). To characterize this Kunitz inhibitor protein, a phylogenetic analysis with other plant Kunitz inhibitors (Supplementary Fig. S3A) was
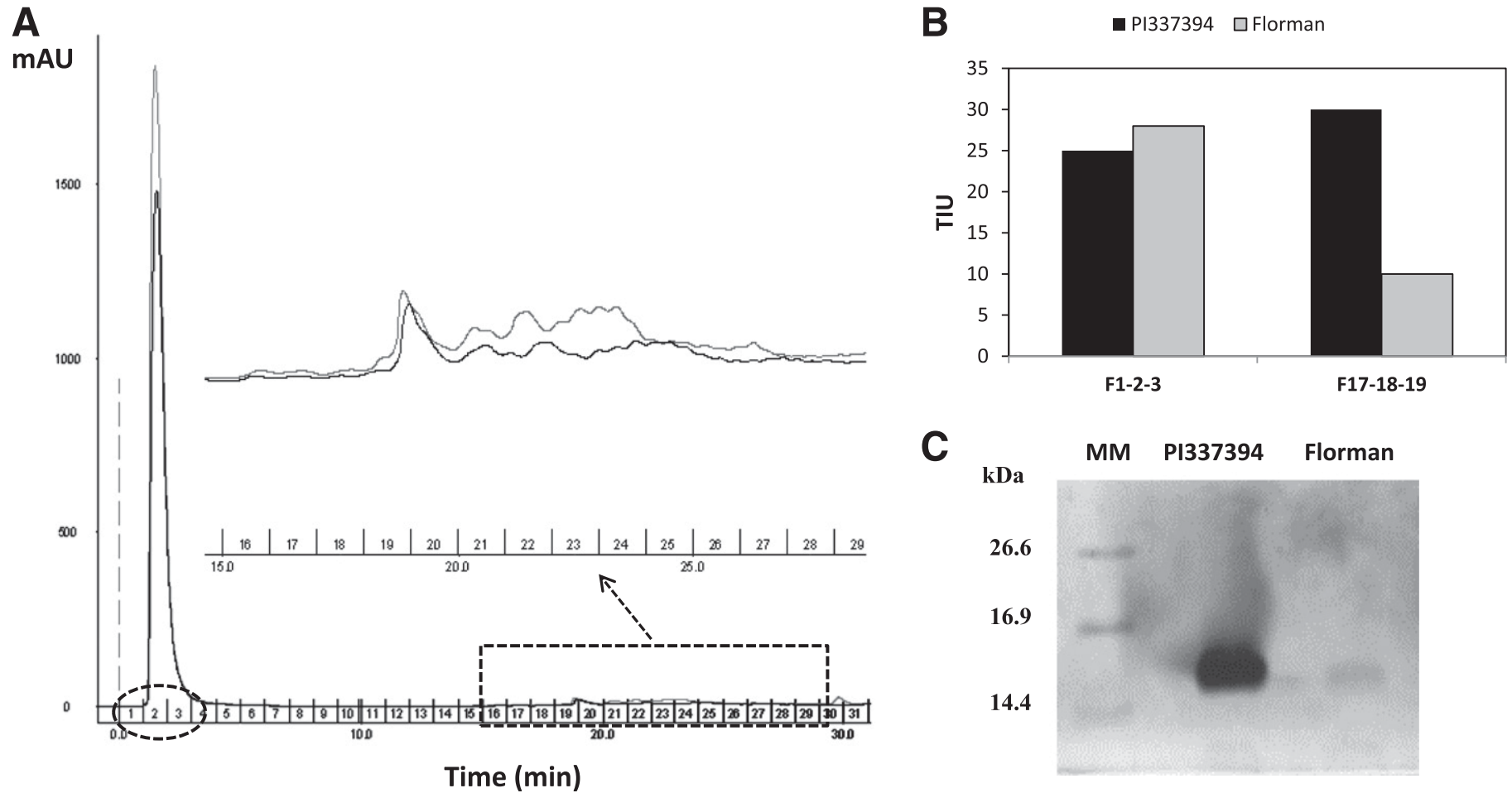

Fig. 1. Purification of plant protease inhibitors (PPI) of infected peanut seeds by anion-exchange chromatography. A, Chromatograms of seed extracts from Florman (gray line) and PI 337394 cultivars (black line). Elution fractions inside ellipses show PPI activity. B, PPI activity of pooled fractions, expressed as trypsin inhibitor units/ml. C, Reverse zymography of pooled fraction 17-18-19 of both cultivars.

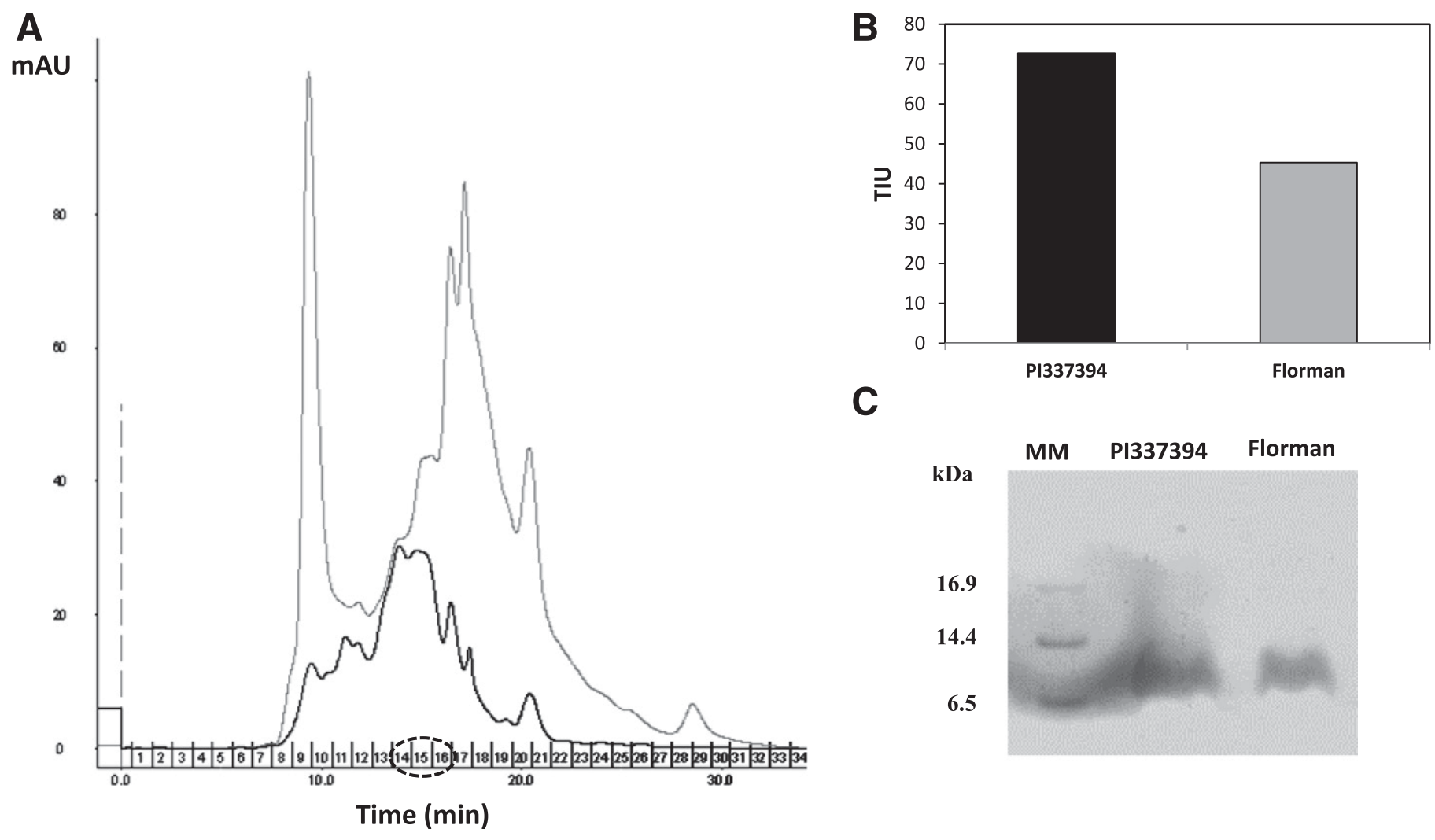

Fig. 2. Purification of plant protease inhibitors (PPI) of infected peanut seeds by gel permeation chromatography. A, Chromatograms of seed extracts from Florman (gray line) and PI 337394 cultivars (black line). Elution fractions inside the ellipse show PPI activity. B, PPI activity of pooled fractions 14-15-16, expressed as trypsin inhibitor units. C, Reverse zymography of pooled fraction 14-15-16 of both cultivars. 
performed. Phylogenetic tree clustered peanut KPI with soybean Kunitz inhibitor (MER017895), two inhibitors of Erythrina variegate (MER017915 and MER019771) and an inhibitor of Psophocarpus tetragonolobus (MER017908). The alignment of these sequences allowed identifying the common regions of Kunitz inhibitors: the characteristic cysteine residues and the active site consisting of lysine, leucine, or arginine residue (Supplementary Fig. S4A).

Likewise, a phylogenetic tree was made for Bowman-Birk trypsin inhibitors (BBTI) of peanut seeds by comparing its sequence with other plant BBTI from the Merops database (http://merops.sanger.ac.uk/). These BBTI were clustered with MER018102 and MER018107-Arachis hypogaea BBTI and the sequence alignment shows that BBTI identified here correspond to the BBTI isoforms previously reported in peanut seed (Norioka and Ikenaka 1983). These peanut BBTI isoforms were also related to BBTI of Medicago (MER025297 and MER024101-Medicago sativa, MER080341-Medicago truncatula), Lens (MER050434-Lens culinaris, MER055331-Lens ervoides, MER055333-Lens nigricans), and Coptis japonica (MER078534). The sequence alignments of BBTIs show two reactive sites formed by an arginine or leucine residue capable of binding to the active site of serine proteases (Birk 1985).

Antifungal activity. In order to evaluate the ability of peanut seed PPIs to inhibit fungal growth, an antifungal assay was performed. A. parasiticus was grown in Mueller Hinton medium in the presence of AEC 17-19 fraction from resistant cultivar (containing KTI). After $24 \mathrm{~h}$ of incubation, fungal growth was determined by microscopic visualization and compared with that in mock-inoculated control. This assay showed a potent inhibitory effect of this protein fraction on the spore germination of A. parasiticus (Fig. 5). When GPC 14-16 fraction containing BBTI was tested, no antifungal activity was detected in both cultivars (Supplementary Fig. S5).

Inhibitory assay of $\boldsymbol{A}$. parasiticus extracellular proteases. To assess the ability of peanut seeds PPI to inhibit $A$. parasiticus proteases, a zymography was performed in the presence of $70 \%$ acetone fraction from resistant cultivar (containing KTI and BBTI isoforms), an inhibitor mix, and mock-inoculated control (Fig. 6). The control showed two main bands corresponding to $91 \mathrm{kDa}$ serine-protease and $43.5 \mathrm{kDa}$ metallo-protease previously reported for A. parasiticus (Asis et al. 2009). The protease activity measured by densitometry showed a reduction of 82 and $90 \%$ of total activity with respect to control, when incubated with inhibitor mix and peanut seed protease inhibitors, respectively. These results reveal the strong inhibitory activity of peanut seed PPIs against those proteases that contribute to $A$. parasiticus virulence.

PPI activity and gene expression during $A$. parasiticus colonization. In order to evaluate the relationship between fungal infection response and PPIs, we measured the PPI activity as trypsin inhibitory units (TIU) in a time series of infected and mock-inoculated control peanut seeds. Different patterns of seed colonization and fold change TIU activity (infected versus control) were observed between cultivars along different infection periods (Fig. 7A and B, respectively). Infected and control seeds of Florman cultivar showed 60 and $4 \%$ of seeds visually colonized by $A$. parasiticus, at $48 \mathrm{~h}$ of infection, respectively. Unlike Florman cultivar, inoculated and control seeds of PI 337394 cultivar did not show colonization at any evaluated infection time (Fig. 7A). Infected Florman seeds showed a twofold increase of TIU with respect to that in control seeds at 5 hai. Unlike that, infected seeds from PI 337394 exhibited a fivefold increase in TIU activity at 48 hai (Fig. 7B).

To evaluate gene expression of $B B T I$ and $K P I$, primers were designed from gene sequences (AY330200.1 and DQ889567.1) encoding PPI proteins identified in the two-dimensional electrophoresis (Table 1). Gene expression was assessed in peanut seeds at different infection times with A. parasiticus and was expressed as fold changes in relation to that in mock-inoculated control seeds (Fig. 7C and D). Different expression patterns for BBTI gene were observed between cultivars (Fig. 7C). The expression of BBTI in PI 337394 cultivar was significantly up-regulated at 20 hai, followed by a strong down-regulation up to 48 hai in response to fungal infection. By contrast, fold change analysis of BBTI in Florman did not display significant changes up to 27 hai followed by a strong downregulation at 48 hai with respect to control seeds.

The expression of $K P I$ showed differences in relation to $B B T I$ expression and between both cultivars (Fig. 7D). In PI 337394, KPI exhibited an up-regulation at 5, 10, and 27 hai and a strong downregulation at 48 hai in response to fungal infection. By contrast, in Florman cultivar KPI expression showed a strong down-regulation from 27 to 48 hai in response to fungal infection.

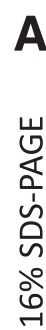

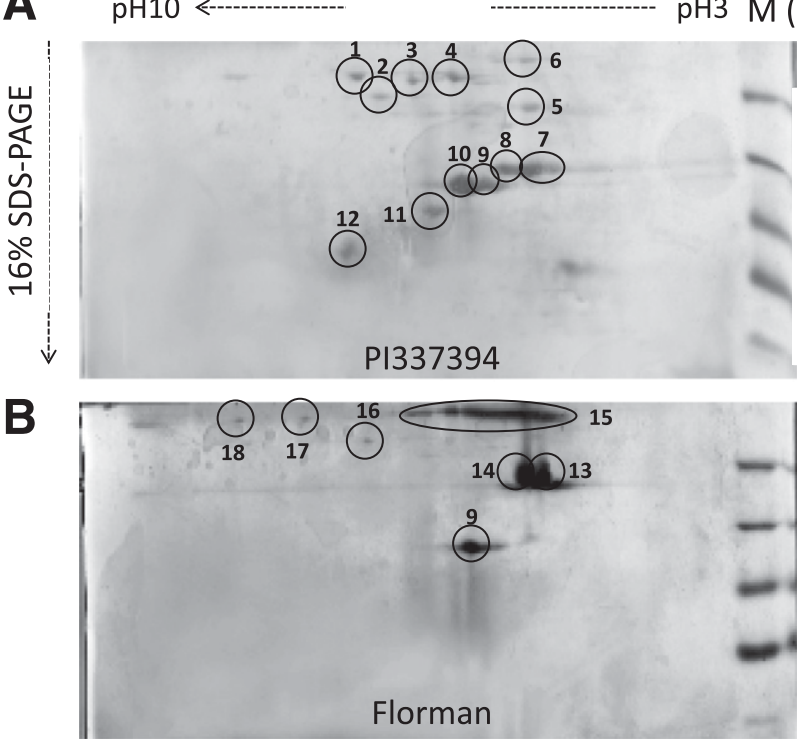

Fig. 3. Seed protein profiles of anion exchange chromatography elution fractions of A, PI 337394 and B, Florman cultivars resolved in 2D-electrophoresis. Seed proteins were separated on $7 \mathrm{~cm}$ IPG ( $\mathrm{pH} 3$ to 10) strips in the first dimension followed by Tris-tricine sodium dodecyl sulfate-polyacrylamide gel electrophoresis $(16 \%)$.

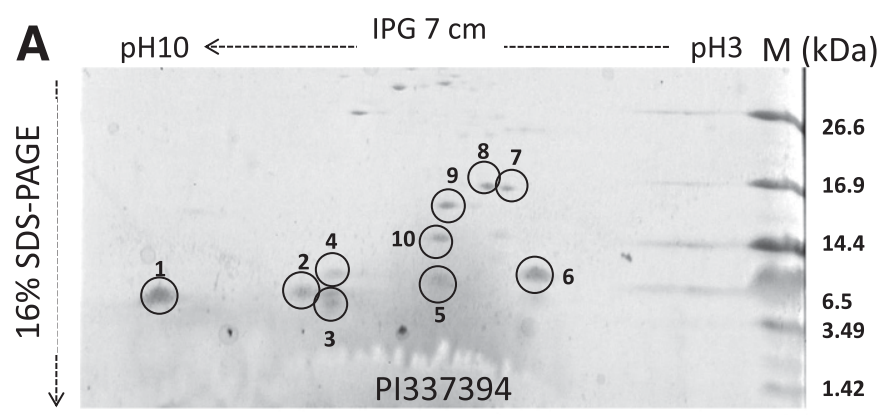

B

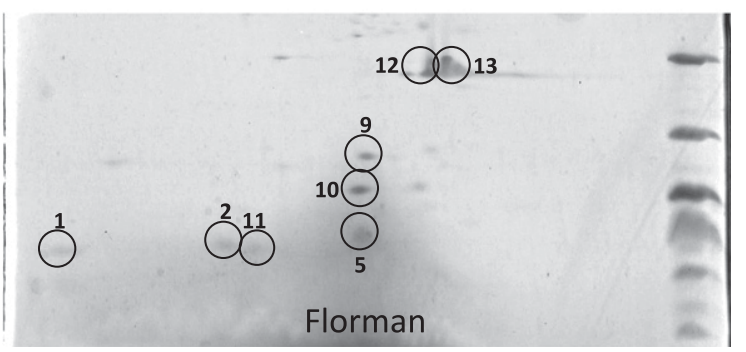

Fig. 4. Seed protein profiles of gel permeation chromatography elution fractions of A, PI 337394 and B, Florman cultivars resolved in 2D-electrophoresis. Seed proteins were separated on $7 \mathrm{~cm}$ IPG (pH 3 to 10) strips in the first dimension followed by Tris-tricine sodium dodecyl sulfate-polyacrylamide gel electrophoresis (16\%). 


\section{DISCUSSION}

PPIs are low molecular weight proteins which occur in several physiological processes and in response to different stresses (reviewed by Hörger and van der Hoorn 2013; Mosolov and Valueva 2005; Yarullina et al. 2016). In this study we have identified and characterized, at biochemical and molecular levels, protease inhibitors produced in peanut seeds during A. parasiticus colonization. To evaluate the regulation and participation of PPIs in seed defense, we have proposed to work with a model of two cultivars distinguished as resistant (PI 337394) and susceptible (Florman INTA) to Aspergillus spp. infection and aflatoxin contamination (Asis et al. 2005). We isolated by chromatographic and electrophoretic methods two protease inhibitors, which occurred in the resistant and susceptible cultivar in response to A. parasiticus colonization. One protease inhibitor was identified as a Bowman-Birk type trypsin inhibitor (BBTI)

TABLE 2. Protein identification by LC-MALDI TOF/TOF of anionic exchange chromatography fractions

\begin{tabular}{|c|c|c|c|c|c|c|c|c|c|}
\hline $\begin{array}{l}\text { Spot } \\
\text { number }\end{array}$ & Cultivar & $\begin{array}{c}\text { NCBI } \\
\text { accession no. }\end{array}$ & Uni Prot no. & $\begin{array}{c}\mathrm{MW}(\mathrm{kDa}) / \mathrm{pI} \\
\text { (theoretical) }\end{array}$ & $\begin{array}{c}\mathrm{MW}(\mathrm{kDa}) / \mathrm{pI} \\
\text { (observed) }\end{array}$ & $\begin{array}{l}\text { Identified } \\
\text { peptides }\end{array}$ & $\begin{array}{l}\text { MASCOT } \\
\text { score }\end{array}$ & $\begin{array}{l}\text { Sequence } \\
\text { coverage }\end{array}$ & Protein \\
\hline 1 & $\mathrm{R}$ & ES721458 & gi|2827080 & $16.32 / 8.56$ & $25.76 / 7.47$ & 5 & 423 & 61 & Malate dehydrogenase \\
\hline 2 & $\mathrm{R}$ & ES711412 & gi|77540216 & $23.59 / 7.14$ & $23.91 / 7.11$ & 4 & 251 & 38 & Triosephosphate isomerase \\
\hline 3 & $\mathrm{R}$ & ES717793 & gi|15221116 & $25.34 / 5.09$ & $25.15 / 6.79$ & 3 & 256 & 33 & $\begin{array}{l}\text { Lactoylglutathione lyase-like } \\
\text { protein }\end{array}$ \\
\hline 4 & $\mathrm{R}$ & GO328251 & gi|211906514 & $29.23 / 9.29$ & $25.46 / 6.30$ & 4 & 211 & 25 & Lactoylglutathione lyase \\
\hline 5 & $\mathrm{R}$ & GO333190 & gi| 351720955 & $25.86 / 5.49$ & $22.37 / 5.44$ & 5 & 309 & 47 & Glutathione-S-transferase \\
\hline 6 & $\mathrm{R}$ & JK157460 & & $18.36 / 4.89$ & $27.00 / 5.46$ & 5 & 331 & 51 & Unknown \\
\hline 7 & $\mathrm{R}$ & ES761053 & gi|18143656 & $20.71 / 6.78$ & $16.82 / 5.44$ & 2 & 164 & 14 & Kunitz trypsin inhibitor p20 \\
\hline 8 & $\mathrm{R}$ & EE124471 & gi| $|145904610|$ & $29.29 / 5.91$ & $16.82 / 5.71$ & 5 & 112 & 32 & Ara h 8 allergen isoform \\
\hline 9 & $\mathrm{R}$ and $\mathrm{S}$ & EE125497 & gi|71040665 & 26.64/6.04 & $15.58 / 5.94$ & 3 & 126 & 24 & $\mathrm{Cu}-\mathrm{Zn}$ superoxide dismutase \\
\hline 10 & $\mathrm{R}$ & EE125497 & gi|71040665 & $26.64 / 6.04$ & $15.58 / 6.21$ & 5 & 203 & 34 & $\mathrm{Cu}-\mathrm{Zn}$ superoxide dismutase \\
\hline 11 & $\mathrm{R}$ & & gi|71040665 & $15.09 / 5.27$ & $13.11 / 6.57$ & 3 & 85 & 44 & $\mathrm{Cu}-\mathrm{Zn}$ superoxide dismutase \\
\hline 12 & $\mathrm{R}$ & EY396114 & gi $|255540625|$ & $12.75 / 7.79$ & $9.41 / 7.52$ & 1 & 122 & 29 & Glutaredoxin-like protein \\
\hline 13 & $\mathrm{~S}$ & ES705001 & gi| 1942899 & $22.98 / 5.32$ & $23.71 / 5.03$ & 13 & 342 & 85 & Chain $\mathrm{A}$, peanut lectin \\
\hline 14 & $\mathrm{~S}$ & ES705001 & gi|1942899 & $22.98 / 5.32$ & $23.71 / 5.21$ & 14 & 321 & 86 & Chain $\mathrm{A}$, peanut lectin \\
\hline 15 & $\mathrm{~S}$ & EG529656 & gi|1942899 & $21.58 / 8.73$ & $11.28 / 5.89$ & 3 & 98 & 31 & Peanut lectin \\
\hline 16 & $\mathrm{~S}$ & GO333162 & gi|2827080 & $22.58 / 10$ & $27.22 / 7.06$ & 9 & 256 & 52 & Malate dehydrogenase \\
\hline 17 & $\mathrm{~S}$ & EG357735 & XP_002525645.1 & $31.72 / 7.71$ & $29.46 / 7.74$ & 5 & 156 & 27 & $\begin{array}{l}\text { Epidermis-specific secreted } \\
\text { glycoprotein EP1 }\end{array}$ \\
\hline 18 & $\mathrm{~S}$ & JK209541 & emb|CAA61158.1| & $20.11 / 9.22$ & $29.46 / 8.55$ & 4 & 263 & 39 & Glycoprotein EP1 \\
\hline
\end{tabular}

TABLE 3. Protein identification by LC-MALDI TOF/TOF of gel permeation chromatography fractions

\begin{tabular}{|c|c|c|c|c|c|c|c|c|c|}
\hline $\begin{array}{l}\text { Spot } \\
\text { number }\end{array}$ & Cultivar & $\begin{array}{c}\text { NCBI } \\
\text { accession no. }\end{array}$ & Uni Prot no. & $\begin{array}{l}\mathrm{MW}(\mathrm{kDa}) / \mathrm{pI} \\
\text { (theoretical) }\end{array}$ & $\begin{array}{c}\text { MW }(\mathrm{kDa}) / \mathrm{pI} \\
\text { (observed) }\end{array}$ & $\begin{array}{l}\text { Identified } \\
\text { peptides }\end{array}$ & $\begin{array}{l}\text { MASCOT } \\
\text { score }\end{array}$ & $\begin{array}{l}\text { Sequence } \\
\text { coverage }\end{array}$ & Protein \\
\hline 1 & $\mathrm{R}$ and $\mathrm{S}$ & & gi|351206 & $6736 / 7.53$ & $5251 / 9.125$ & 4 & 169 & 86 & Inhibitor BIII trypsin chymotrypsin \\
\hline 2 & $\mathrm{R}$ and $\mathrm{S}$ & & gi 351443 & $6965 / 6.67$ & $5487 / 7.37$ & 3 & 106 & 74 & Inhibitor BI, protease \\
\hline 3 & $\mathrm{R}$ & & gi| 213868275 & & $5251 / 7.11$ & 2 & 210 & & Ubiquitin \\
\hline 4 & $\mathrm{R}$ & EE124396 & & $14313 / 8.48$ & $8024 / 7.02$ & 5 & 165 & 60 & Similar to glutaredoxin \\
\hline 5 & $\mathrm{R}$ and $\mathrm{S}$ & & gi|33090235 & $8698 / 5.07$ & $7232 / 5.75$ & 5 & 94 & 100 & Bowman-Birk trypsin inhibitor A-I \\
\hline 6 & $\mathrm{R}$ & & gi|124020 & $7628 / 5.08$ & $8421 / 4.57$ & 4 & 121 & 88 & $\begin{array}{l}\text { Bowman-Birk type protease } \\
\text { inhibitor A-II }\end{array}$ \\
\hline 7 & $\mathrm{R}$ & & gi| 145904610 & $16402 / 5.07$ & $17533 / 5.01$ & 4 & 187 & 53 & Ara h 8 allergen isoform \\
\hline 8 & $\mathrm{R}$ & & gi 145904610 & $16402 / 5.07$ & $17930 / 5.19$ & 4 & 175 & 53 & Ara h 8 allergen isoform \\
\hline 9 & $\mathrm{R}$ and $\mathrm{S}$ & & gi|71040665 & $15089 / 5.27$ & $15552 / 5.67$ & 3 & 107 & 38 & $\mathrm{Cu}-\mathrm{Zn}$ superoxide dismutase \\
\hline 10 & $\mathrm{R}$ and $\mathrm{S}$ & & gi|53830013 & $10018 / 6.73$ & $12382 / 5.75$ & 3 & 124 & 69 & $\mathrm{PR}$ protein $4 \mathrm{~A}$ \\
\hline 11 & $\mathrm{~S}$ & ES703500 & & $20035 / 9.23$ & $5647 / 7.11$ & 3 & 123 & 21 & Acyl-CoA-binding protein \\
\hline 12 & $\mathrm{~S}$ & & gi|1942899 & $25174 / 4.99$ & $25457 / 4.84$ & 6 & 322 & 42 & Chain $\mathrm{A}$, peanut lectin \\
\hline 13 & $\mathrm{~S}$ & & gi| 1942899 & $25174 / 4.99$ & $25457 / 4.58$ & 5 & 337 & 45 & Chain $\mathrm{A}$, peanut lectin \\
\hline
\end{tabular}

A

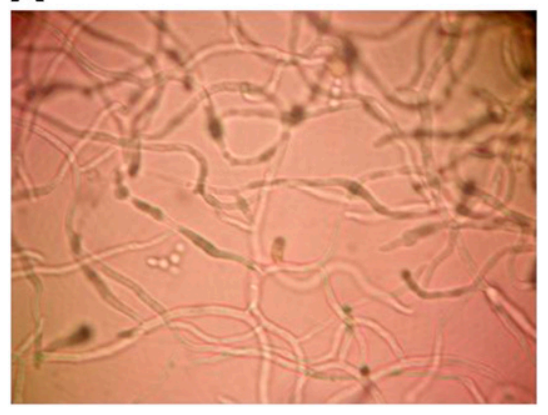

B

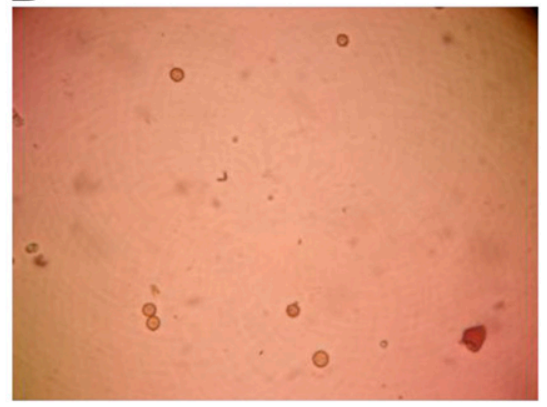

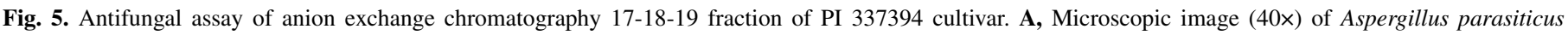

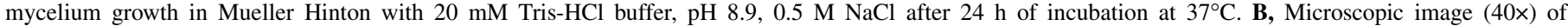
A. parasiticus mycelium growth in Mueller Hinton with fraction anion exchange chromatography 17-19 (20 $\mu \mathrm{g}$ of protein). 


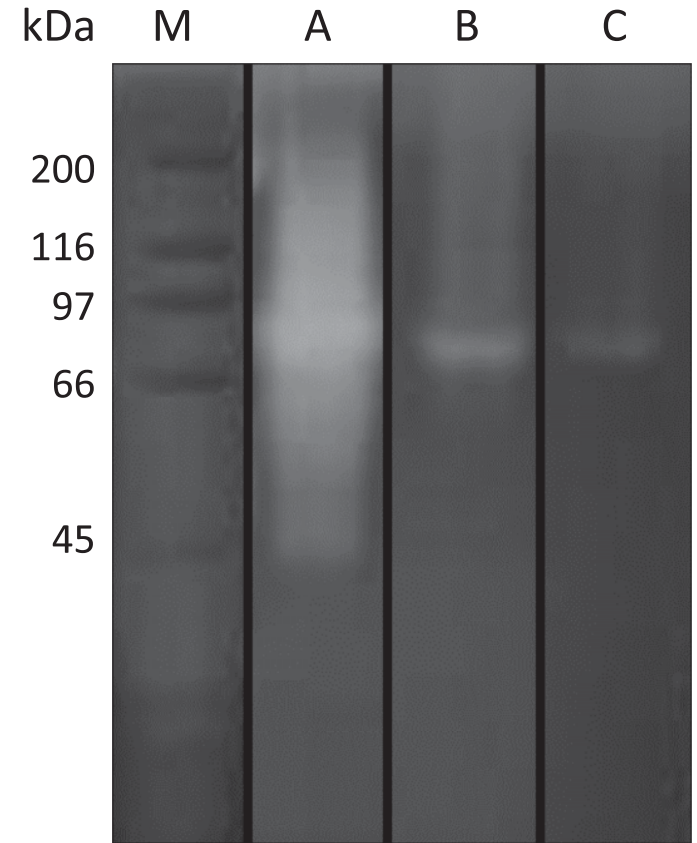

Fig. 6. Zymography of Aspergillus parasiticus extracellular proteases. A, Proteases incubated in the absence of inhibitors. B, Proteases incubated with inhibitors mix (EDTA, PMSF, iodoacetamide, and pepstatin A). C, Proteases incubated with peanut plant protease inhibitors obtained by precipitation with acetone $70 \%$ ( $\mathrm{vol} / \mathrm{vol})$. previously reported and characterized in peanut seed (Norioka 1983). The other was identified as a Kunitz-type protease inhibitor (KPI), which to our knowledge, has not been previously reported. The KPI sequence is closer to Fabaceae Kunitz-type protease inhibitor of Glycine max (MER017895), Erythrina variegate (MER017915 and MER019771), and Psophocarpus tetragonolobus (MER017908).

The occurrence of KPI and BBTI at $48 \mathrm{~h}$ after A. parasiticus inoculation was noticeably different between cultivars (Figs. 3 and 4, respectively). KPI was detected only in the resistant cultivar (Fig. 3 ), while BBTI isoforms were produced in a higher concentration, showing an extra isoform (BBTI AII) as compared with that in the susceptible cultivar (Fig. 4). These results agree with those of previous studies where protease inhibitor genes of peanut seed were differentially expressed between resistant (GT-C20 and A13) and susceptible (Tifrunner) cultivars in response to $A$. parasiticus infection (Luo et al. 2005a, b; Guo et al. 2008, 2011). Within this gene group, BBTI, cysteine protease inhibitor and KPI (different from KPI reported here) were found higher expressed in the resistant cultivars. In another study, protease inhibitors containing cupin domain were down-regulated in response to infection of toxigenic and nontoxigenic $A$. flavus strains in a susceptible peanut cultivar (Luhua 14) (Wang et al. 2012). All these results evidence a protease inhibitor participation in response to Aspergillus spp. infection; this response being dependent on peanut genotype rather than on Aspergillus species or their aflatoxigenic capacity. In addition to PPIs, other proteins identified in our resistant cultivar (glutaredoxin, superoxide dismutase, Ara h 8, glutathione-S-transferase, lactoylglutathione lyase, or glyoxalase) were also found highly expressed in
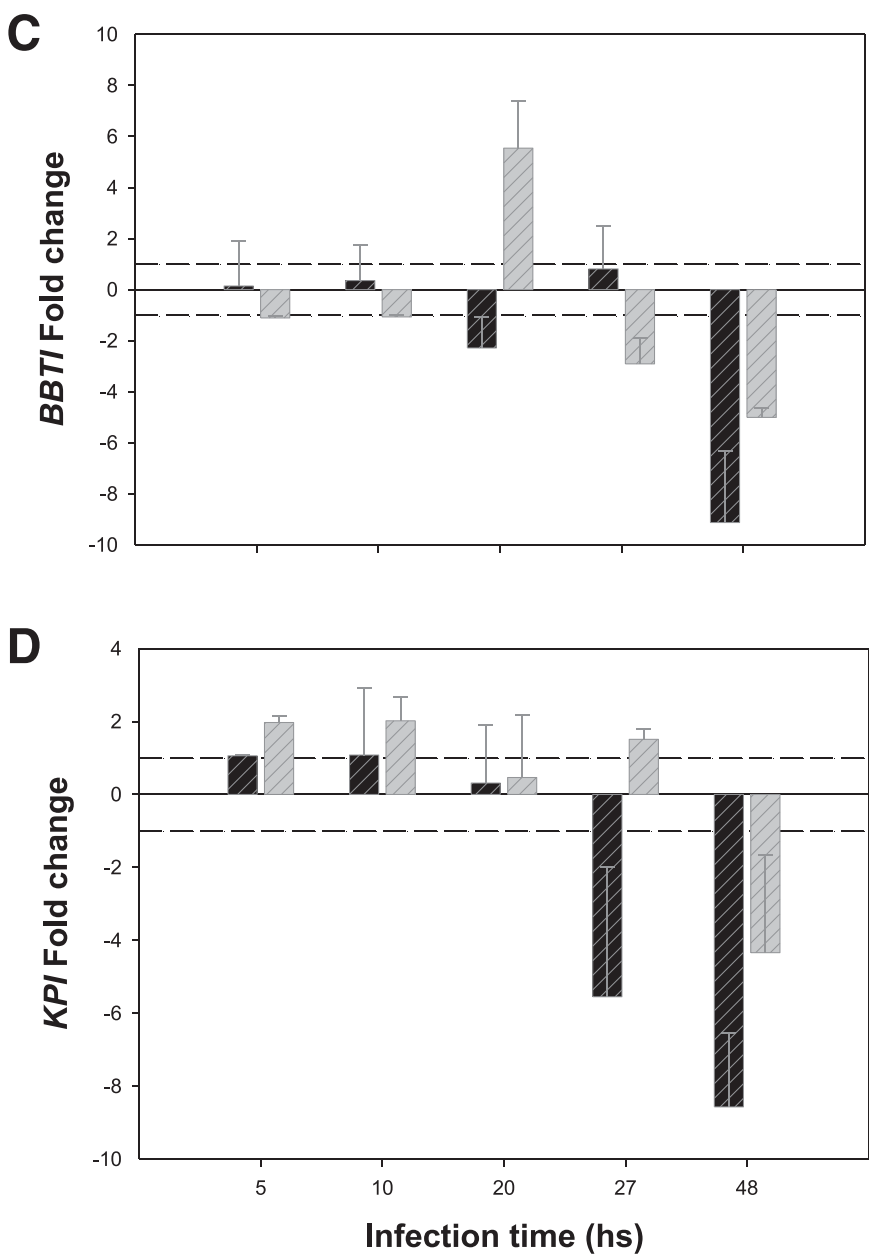

Infection time (hs)

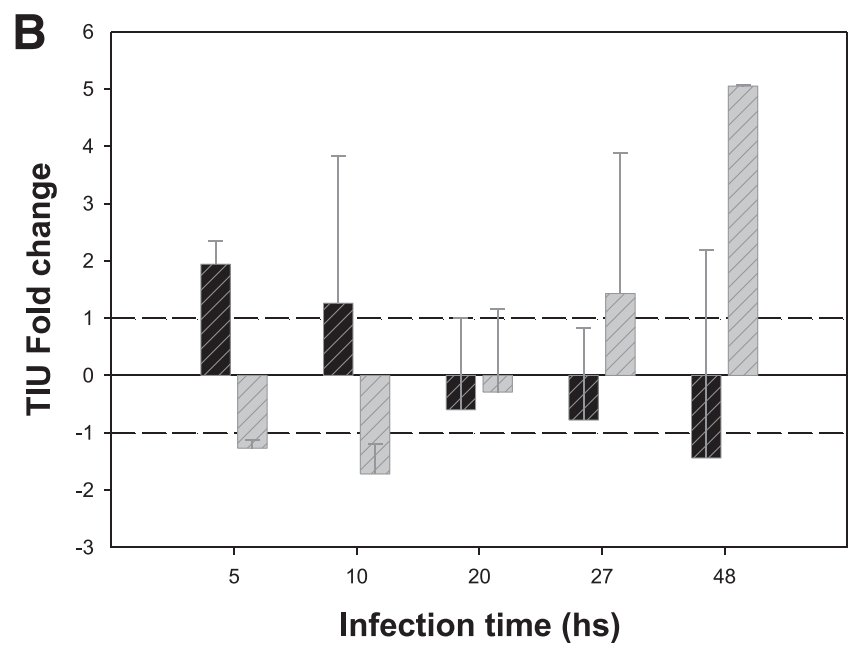

Fig. 7. Visual infection, trypsin inhibitory unit activity (TIU) and qRT-PCR analysis of BBTI and KPI genes in PI 337394 cultivar (black bars) and Florman INTA cultivar (gray bars). TIU and gene expression are represented as the mean \pm SD of fold change of infected seeds from three biological replicates with respect to the average value of control seeds corresponding to the same time after inoculation. Values between 1 and -1 mean do not change with respect to those of the control. A, Percentage of infected seeds. B, Fold change of TIU. C, Fold change of BBTI. D, Fold change of KPI. 
other resistant cultivars (Guo et al. 2008, 2011; Luo et al. 2005a, b). These results evidence the role of these proteins related to stress into peanut seed resistance against to Aspergillus species.

We have previously reported that the involvement of extracellular proteases of $A$. parasiticus in the fungal colonization of peanut seed affected seed viability, inducing tissue necrosis and promoting fungal colonization and aflatoxin production (Asis et al. 2009). On the basis of this study, we assessed the ability of protease inhibitors to modulate the activity of $A$. parasiticus extracellular proteases. Our results indicated a marked inhibitory effect on $A$. parasiticus protease activity (Fig. 6). These finding suggest that peanut protease inhibitors can be involved in the seed defense reducing the action of fungal proteases.

Another mechanism involving certain PPIs in plant defense is their antimicrobial capacity. When we evaluated the antifungal activity of chromatographic fractions containing BBTI, they did not show antifungal activity against $A$. parasiticus. In contrast, chromatographic fractions containing KPI displayed a strong antifungal activity against A. parasiticus. Because this fraction is composed of several proteins (Table 2), it is difficult to ascribe antifungal activity to KPI. However, several studies have shown that Kunitz inhibitors produce insecticide or antifeedant activity and also antifungal activity against plant pathogenic fungi. An example is the soybean Kunitz inhibitor, homologous to peanut KPI, which has the ability to inhibit Fusarium oxysporum (Wang and $\mathrm{Ng}$ 2006). Another inhibitor is the Acacia plumose Kunitz inhibitor, highly homologous to Acacia confuse Kunitz inhibitor, that showed antifungal activity against Aspergillus niger, Colletotrichum sp., and Fusarium moniliforme (Lopes et al. 2009).

To examine the genetic response of protease inhibitors to $A$. parasiticus infection, expression of $K P I$ and $B B T I$ genes along with trypsin inhibitory activity was analyzed in infected and control seeds of both cultivars at postinfection time references. The results showed a differential temporal response between cultivars. In the seed of resistant cultivar, the trypsin inhibitory activity was increased at 48 hai (Fig. 7B) and the expression of KPI and BBTI gene was moderately up-regulated from 5 to 27 hai, and 20 hai, respectively (Fig. 7C and D). Gene expression analyses showed that expression of both protease inhibitors would be contributing to the increase of trypsin inhibitory activity described in the resistant cultivar. In contrast, the trypsin inhibitory activity in the susceptible cultivar was slightly increased in the early hours of infection (Fig. 7B). However, in this cultivar $K P I$ and $B B T I$ gene expression did not show significant changes between infected and control seeds at earlier times of infection (Fig. 7C and D). In this cultivar, only the presence of BBTI isoforms was detected at 48 hai (Tables 2 and 3) and it is likely that overexpression of $B B T I$ gene at earlier times had contributed to increasing trypsin inhibitory activity. Five BBTI isoforms have been previously described in peanut seed (Norioka 1983). The high identity of four of them (BIII, BI, AI, and AII isoforms) suggests that they are code for same gene and isoforms originate from posttranslational cleavage, while the remaining isoforms (BII isoform) derive from an unknown gene (Boateng et al. 2005). Considering the differences in BBTI isoform composition and gene expression between cultivars, BBTI response to fungal infection was differentially regulated at transcriptional and posttranscriptional levels between cultivars.

In conclusion, two types of PPIs that occurred during A. parasiticus infection were identified as Kunitz-type inhibitor and BBTI isoforms AI, AII, BI, and BIII. The results of this study showed a different temporal response of PPIs in seeds of two peanut cultivars challenged by $A$. parasiticus infection. In the susceptible cultivar an early PPI activity response, mainly associated with BBTI occurrence, was observed. Meanwhile in the resistant cultivar a later response with a larger increase in PPI activity was described as being associated with BBTI and KPI occurrence. The participation of these compounds in seed defense against fungal infection would be caused by the action of inhibiting extracellular enzymes that release the fungus during infection and by the antifungal effect of KPI produced by an unknown mechanism.
In the light of the results reported, it can be considered that Aspergillus spp. resistance in peanut seed is closely related to PPIs occurrence and to a novel Kunitz-type trypsin inhibitor. A genetic regulation of PPIs was clearly evidenced in the resistant cultivar in response to fungal infection. It is known that lipoxygenase (LOX) pathway products, such as jasmonates, are one of the major regulators of PPI gene expression (Christensen et al. 2015). In a previous study, we have reported a differential LOX activation in response to A. parasiticus infection using the same cultivar studied here Müller et al. (2014). In both cultivars we observed an early response of LOX activity to fungal infection. However, a different composition of LOX enzyme driven by a differential co-expression of three $L O X$ genes was found between cultivars. In these contexts, unraveling this network will challenge the understanding of the bases of peanut seed resistance to Aspergillus spp. infection and aflatoxin contamination.

\section{ACKNOWLEDGMENTS}

V. Müller is a recipient of a fellowship of Consejo Nacional de Investigaciones Científicas y Técnicas (CONICET), Argentina. V. Amé, F. Carrari, G. Batthyany, and R. Asis are members of Consejo Nacional de Investigaciones Científicas y Técnicas (Argentina). This work was partially financed by Instituto Nacional de Tecnología Agropecuaria (INTA), CONICET, Agencia Nacional de Promoción Científica y Tecnológica (ANPCyT) and Secretaria de Ciencia y Tecnología (SeCyT), UNC. We thank C. Mosconi for linguistic revision of the manuscript.

\section{LITERATURE CITED}

Asis, R., Barrionuevo, D. L., Giorda, L. M., Nores, M. L., and Aldao, M. A. 2005. Aflatoxin Production in six peanut (Arachis hypogaea L.) genotypes infected with Aspergillus flavus and A. parasiticus, isolated from peanut production areas of Cordoba, Argentina. J. Agric. Food Chem. 53:9274-9280.

Asis, R., Muller, V., Barrionuevo, D. L., Araujo, S. A., and Aldao, M. A. 2009. Analysis of protease activity in Aspergillus flavus and A. parasiticus on peanut seed infection and aflatoxin contamination. Eur. J. Plant Pathol. 124:391-403.

Birk, Y. 1985. The Bowman-Birk inhibitor. Trypsin- and chymotrypsininhibitor from soybeans. Int. J. Pept. Protein Res. 25:113-131.

Boateng, J. A., Viquez, O. M., Konan, K. N., and Dodo, H. W. 2005. Screening of a peanut (Arachis hypogaea L.) cDNA library to isolate a Bowman-Birk trypsin inhibitor clone. J. Agric. Food Chem. 53:2028-2031.

Carrillo, L., Herrero, I., Cambra, I., Sánchez-Monge, R., Diaz, I., and Martinez, M. 2011. Differential in vitro and in vivo effect of barley cysteine and serine protease inhibitors on phytopathogenic microorganisms. Plant Physiol. Biochem. 49:1191-1200.

Chen, Z. Y., Brown, L. R., Guo, B. Z., Menkir, A., and Cleveland, T. E. 2009. Identifying aflatoxin resistance related proteins/genes through proteomics and RNAi gene silencing. Peanut Sci. 36:35-41.

Chen, Z. Y., Brown, R. L., Lax, A. R., Cleveland, T. E., and Russin, J. S. 1999. A. Inhibition of plant-pathogenic fungi by a corn trypsin inhibitor overexpressed in Escherichia coli. Appl. Environ. Microbiol. 65:1320-1324.

Christensen, S. A., Huffaker, A., Kaplan, F., Sims, J., Ziemann, S., and Doehlemann, G. 2015. Maize death acids, 9-lipoxygenase-derived cyclopente(a)nones, display activity as cytotoxic phytoalexins and transcriptional mediators. Proc. Natl. Acad. Sci. 112:11407-11412.

Guo, B., Chen, X., Dang, P., Scully, B. T., Liang, X., Holbrook, C. C., Yu, J., and Culbreath, A. K. 2008. Peanut gene expression profiling in developing seeds at different reproduction stages during Aspergillus parasiticus infection. BMC Dev. Biol. 8:12.

Guo, B., Fedorova, N. D., Chen, X., Wan, C., Wang, W., Nierman, W. C., Deepak, B., and Yu, J. 2011. Gene expression profiling and identification of resistance genes to Aspergillus flavus infection in peanut through EST and microarray strategies. Toxins (Basel) 3:737-753.

Hörger, A. C., and van der Hoorn, R. A. L. 2013. The structural basis of specific protease-inhibitor interactions at the plant-pathogen interface. Curr. Opin. Struct. Biol. 23:842-850.

InfoStat. 2002. Grupo InfoStat Professional. Facultad de Ciencias Agropecuarias, Universidad Nacional de Córdoba, Argentina.

Joshi, B. N., Sainani, M. N., Bastawade, K. B., Gupta, V. S., and Ranjekar, P. K. 1998. Cysteine protease inhibitor from pearl millet: A new class of antifungal protein. Biochem. Biophys. Res. Commun. 246:382-387.

Kouzuma, Y. H., Inanaga, H., Doi-Kawano, K., Yamasaki, N., and Kimura, M. 2000. Molecular cloning and functional expression of cDNA encoding the cysteine proteinase inhibitor with three cystatin domains from sunflower seeds. J. Biochem. 128:161-166. 
Lopes, J. L. S., Valadares, N. F., Moraes, D. I., Rosa, J. C., Araújo, H. S. S., and Beltramini, L. M. 2009. Physico-chemical and antifungal properties of protease inhibitors from Acacia plumosa. Phytochemistry 70: 871-879.

Luo, M., Dang, P., Guo, B. Z., He, G., Holbrook, C. C., Bausher, M. G., and Lee, R. D. 2005a. Generation of expressed sequence tags (ESTs) for gene discovery and marker development in cultivated peanut. Crop Sci. 45: 346-353.

Luo, M., Liang, X. Q., Dang, P., Holbrook, C. C., Bausher, M. G., Lee, R. D., and Guo, B. Z. 2005b. Microarray-based screening of differentially expressed genes in peanut in response to Aspergillus parasiticus infection and drought stress. Plant Sci. 169:695-703.

Mosolov, V. V., and Valueva, T. A. 2005. Proteinase inhibitors and their function in plants: A review. Appl. Biochem. Microbiol. 41:227-246.

Müller, V., Amé, M. V., Carrari, F., Gieco, J., and Asis, R. 2014. Lipoxygenase activation in peanut seed cultivars resistant and susceptible to Aspergillus parasiticus colonization. Phytopathology 104:1340-1348.

Norioka, S., and Ikenaka, T. 1983. Amino acid sequences of trypsin chymotrypsin inhibitors (AI, AII, BI, BII, BIII) from peanut (Arachis hypogaea): A discussion on the molecular evolution of legumes Bowman-Birk type inhibitors. J. Biochem. 94:589-599.
Park, K. S., Cheong, J. J., Lee, S. J., Suh, M. C., and Choi, D. 2000. A novel proteinase inhibitor gene transiently induced by tobacco mosaic virus infection. Biochim. Biophys. Acta 1492:509-512.

Roberts, W., and Selitrennikoff, C. P. 1990. Zeamatin, an antifungal protein from maize with membrane-permeabiliziting activity. J. Gen. Microbiol. 136:1771-1778.

Schägger, H. 2006. Tricine-SDS-PAGE. Nat. Protoc. 1:16-22.

Schneider, C. A., Rasband, W. S., and Eliceiri, K. W. 2012. NIH image to ImageJ: 25 years of image analysis. Nat. Methods 9:671-675.

Vernekar, J. V. G., and Deshpande, M. S. 1999. Alkaline protease inhibitor: A novel class of antifungal proteins against phytopathogenic fungi. Biochem. Biophys. Res. Commun. 262:702-707.

Wang, H. X., and Ng, T. B. 2006. Concurrent isolation of a Kunitz-type trypsin inhibitor with antifungal activity and a novel lectin from pseudostellaria heterophylla roots. Biochem. Biophys. Res. Commun. 342:349-353.

Wang, Z., Yan, S., Liu, C., Chen, F., and Wang, T. 2012. Proteomic analysis reveals an aflatoxin-triggered immune response in cotyledons of Arachis hypogaea infected with Aspergillus flavus. J. Proteome Res. 11:2739-2753.

Yarullina, L. G., Akhatova, A. R., and Kasimova, R. I. 2016. Hydrolytic enzymes and their proteinaceous inhibitors in regulation of plant-pathogen interactions. Russ. J. Plant Physiol. 63:193-203. 